\title{
Spirituality in Renal Failure Patients with Hemodialysis
}

\author{
${ }^{1 s t}$ Adiratna Sekar Siwi \\ Faculty of Health, Harapan Bangsa \\ University \\ adiratnasiwi@gmail.com
}

\author{
${ }^{2 n d}$ Azka Fathiyatir Rizqillah \\ Faculty of Health, Harapan Bangsa \\ University \\ fathiya.azka@gmail.com
}

\author{
${ }^{3 r d}$ Amalia Lestari \\ Faculty of Health, Harapan Bangsa \\ University \\ amalia.lestari21@ymail.com
}

\begin{abstract}
Patients with chronic renal failure who do hemodialysis can reduce the risk of damage to vital organs due to accumulation of toxic substances in the circulation, but this action does not heal or restore kidney function permanently. Patients undergoing long-term hemodialysis will face various problems, such as lack of control over the activities of daily life and social life. Chronic renal failure is a terminal illness that will affect the patient's quality of life, including their spirituality. Spiritual issues are considered to have effects in patients with renal failure who undergoing hemodialysis. Spiritual considered to be able to maintain an optimistic perspective that may impact on increasing immunity. This research uses descriptive research design. The sample size in this study are 58 respondents. The total sampling technique were used. The research instrument was a questionnaire Daily Spiritual Experience Scale (DSES). The data in this research were analyzed by using frequency distribution. The results showed a large majority of respondents had elderly age category (46-65 years) as many as 37 respondents (63.8\%), and male sex were 32 respondents $(55.2 \%)$ and patient who underwent Haemodyalisis for less than 6 months were 38 respondents (65.5\%). Most respondents have a high spirituality as much as 48 respondents (82.8\%). The need for special assessments related to the patient's spiritual, so that health professionals can implement to address spiritual problems of patients .
\end{abstract}

Keywords: spirituality, renal failure, hemodialysis

\section{INTRODUCTION}

Chronic kidney failure is a terminal disease that will affect the quality of life of patients. Patients undergoing hemodialysis will experience changes in daily life and social activities. This results in psychosocial problems, such as the inability to continue his normal lifestyle, independence in living a life of anxiety, depression, social isolation, loneliness, helplessness, and despair [1]. It was stated that spiritual problems were considered to have a role in some of the effects experienced by kidney failure patients undergoing hemodialysis. Spiritual is considered able to maintain an optimistic view which can have an impact on increasing immunity [2].

Spirituality contains the understanding of the relationship between humans and their God by using the medium of prayer, fasting, almsgiving, pilgrimage, prayer and so on. In addition, the component of spirituality also consists of human relations with nature, relationships with himself and relationships with others [3].

Spiritual problem is a very important problem for patients suffering from chronic life-threatening diseases, related with that we need to approach the biopsychosocial-spiritual model in treating patients. Spiritual disorders will cause severe psychological disorders including suicidal ideation. For this reason, it is necessary to take a spiritual approach to improve the quality of life of patients with chronic kidney disease undergoing hemodialysis from both families and medical personnel who assist patients in undergoing the process of hemodialysis [3].

\section{METHODOLOGY}

This research employed descriptive research design. The population in this study were all kidney failure patients who underwent haemodialysis for a year. The sample size in this study were 58 respondents. The sampling technique was total sampling. 
This research was conducted in the Haemodialysis room of RST Wijayakusuma Purwokerto. The time of the study was in June 2019.

The instrument used in this study was a questionnaire. Questionnaires using spirituality scale The Daily Spiritual Experience Scale (DSES) was employed to express spirituality in parents. The Daily Spiritual Experience Scale (DSES) consisted of sixteen items with positive statements. Data analysis used in this study was univariate analysis by presenting a frequency distribution.

Daily Spiritual Experience Scale (DSES) used to view spiritual experience and how spirituality influence in everyday life, individual behavior, either in mind, and attitudes. To scatter aitem dses dses chosen in research has been used as a measuring instrument in the study there be 200 spirituality of research, published and have been translated to 40 language. DSES begins to develop and has since 2002 final revisions in 2011 [4].The instruments have been the the validity of building scales, that have been validated by the religion, psychology Dr.Ahmad, S.Ag.,S.Psi.M.Psi. Of the faculty of psychology makassar state university [5].

\section{FINDING AND DISCUSSION}

The number of respondents who met the inclusion criteria in this study was 58 respondents and the obtained results were as follows:

1. Univariate Analysis

a. Characteristics of Respondents (Age, Gender and Length of HD)

Table 1 Frequency Distribution of Respondents (Age, Gender and Length of HD)

\begin{tabular}{|c|c|c|}
\hline Age & Frequency (n) & Percentage $(\%)$ \\
\hline Teenagers $(12-25$ & 1 & 1.7 \\
\hline years old) & 20 & 34.5 \\
\hline $\begin{array}{l}\text { 2. Adults (26-45 } \\
\text { years old) }\end{array}$ & \multirow[t]{2}{*}{37} & \multirow[t]{2}{*}{63.8} \\
\hline $\begin{array}{l}\text { 3. Elderly (46-65 } \\
\text { years old) }\end{array}$ & & \\
\hline Total & 58 & \\
\hline Gender & Frequency (n) & Percentage $(\%)$ \\
\hline Male & 32 & 55.2 \\
\hline 2. Female & 26 & 44.8 \\
\hline Total & 58 & 100 \\
\hline Length of $\mathrm{HD}$ & Frequency (n) & Percentage (\%) \\
\hline 1. Acute (<6 months) & 38 & 65.5 \\
\hline $\begin{array}{l}\text { 2. } \begin{array}{l}\text { Chronic }(\geq 6 \\
\text { months })\end{array}\end{array}$ & 20 & 34.5 \\
\hline Total & 58 & 100 \\
\hline
\end{tabular}

Table 1 showed that most of the respondents were elderly (46-65 years old) i.e. 37 respondents $(63.8 \%)$, and 32 male respondents $(55.2 \%)$ and 38 respondents $(65.5 \%)$ undergoing hemodialysis for less than 6 months.

b. The Spirituality of Respondents Who Underwent Haemodialysis

Table 2 The Spirituality of Respondents Undergoing Hemodialysis

\begin{tabular}{ccc}
\hline Spirituality & $\begin{array}{c}\text { Frequency } \\
(\mathbf{n})\end{array}$ & Percentage (\%) \\
\hline Low Spirituality & 0 & 0 \\
Average Spirituality & 10 & 17.2 \\
High Spirituality & 48 & 82.8 \\
\hline Total & 58 & 100
\end{tabular}

Based on the table 2, it was shown that most respondents had high spirituality, i.e. 48 respondents $(82.8 \%)$.

\section{DISCUSSION}

\section{Characteristics of Respondents (Age, Gender} and Length of HD)

Based on the results of the study, the majority of respondents aged the elderly category (46-65 years) were 37 respondents $(63.8 \%)$. Researchers assumed at the age of 4565 years (elderly), there would be a decrease in the function of one of the organs of the body so that the kidneys could reduce health condition. According to Smelzter and Bare (2012), it was stated that over the age of 40 years, there would be a progressive decrease in glomerular filtration rate to 70 years of approximately $50 \%$ of normal so that there was a decrease in the ability of the kidney tubules to reabsorb and concentrate urine. Decreased ability of the bladder to empty completely resulted in a risk of infection, obstruction and decreased fluid intake, which were risk factors for kidney damage.

Based on the results of the study, most of the respondents were male i.e. 32 respondents $(55.2 \%)$. This result, most respondents were male, totaling 30 respondents $(88.2 \%)$ while women were only 4 respondents $(11.8 \%)$. This revealed that men were far more at risk of chronic kidney failure than women, because women had more estrogen hormones. The hormone estrogen served to inhibit the formation of cytokines to subdue osteoclasts so 
as not to excessively absorb bone, thus calcium levels were balanced. Calcium had a protective effect by preventing the absorption of oxalate which could form kidney stones as one of the causes of chronic kidney failure [6].

The research findings revealed that the majority of respondents having undergone haemodialysis for less than 6 months were 38 respondents $(65.5 \%)$. Researchers assumed that the large number of patients undergoing haemodialysis was still in the acute stage.

2. The Spirituality of Respondents Undergoing Haemodialysis

Based on research results from 58 respondents, it was found that most respondents having high spirituality were 48 respondents $(82.8 \%)$. Researchers assumed that the tests they gave to respondents made them closer to their God, hoping that the more resigned their condition would be, the easier acceptance would be for them. In addition, the stage of development, previous life experiences and the crisis of change could affect the spirituality of each individual [7]. In this study the majority of respondents were aged 45-65 years (elderly).

That most of them having good spirituality were 29 respondents $(90.6 \%)$. The spirituality of patients was influenced by the level of development, where the more age increased, the better one's spirituality was. Families of patients more often prayed for patients to recover from illness and diligently performed worship. In addition, attachment to others (socialization with others) could provide hope for one another [8].

Study on spirituality and found that spirituality had important implications for the clinical care of patients and spirituality was a coping strategy in the present condition. Conditions such as chronic kidney failure had a significant impact on the lives of patients and affected physical, functional, emotional, social and spiritual well-being so that spirituality was very important in restoring patients' health [9]. The spirituality of patients undergoing hemodialysis could help them accept illness, find peace in suffering, live with disease and work together better [10].

\section{IMPLICATION FOR PRACTICE}

Implication is very concern to the or private practice of nursing of the study are as the reference clinical care teams would win in all official would receive any commission health of its people particularly the nurse who often says so as to give intensive maintenance to holistic to the patient with kidney failure of a chronic the remembrance of remaining issue basic design that was allegedly occurred at the patient with kidney failure of a chronic is focused do hemodialysis to maintain physical fitness only a matter of time, while a lot of things to them with kindness reck to the recovery of heath for patients e g bio-psychosocial-spiritual .

\section{CONCLUSIONS}

1. Most respondents had the age category of elderly (46-65 years) i.e. 37 respondents $(63.8 \%)$, and male sex were 32 respondents $(55.2 \%)$ and patients undergoing haemodialysis for less than 6 months were 38 respondents $(65.5 \%)$.

2. Most respondents had high spirituality i.e. 48 respondents $(82.8 \%)$.

\section{REFERENCES}

[1] Kurniawan, Tri. 2017. Hubungan Karakteristik Deangan Kejadian Depresi Pada Penderita Gagal Ginjal Kronik Yang Menjalani Terapi Hemodialisa Di RSUD Majenang 2017. (Digital collection of academic papers, undergraduate thesis \& research). Retrieved from https://repository.shb.ac.id

[2] Hanida, W., Mudjaddid, E., Nasution, H. H., \& Shatri, H. 2016. Korelasi Aspek Spiritual dengan Kadar Interleukin6 Serum pada Pasien Hemodialisis Kronik. Jurnal Penyakit Dalam Indonesia, 3(1), 3-7

[3] Hawari Dadang. 2016. Manajemen Stres Cemas Dan Depresi. Fakultas Kedokteran Universitas Indonesia. Jakarta

[4] Underwood, L. G. \& Teresi, J. 2002. The Daily Spiritual Experience Scale: Development, theoretical description, reliability, exploratory factor analysis, and preliminary construct validity using health related data. Annals of Behavioral Medicine, 24, 22-33.

[5] Fath, N.M.D.E. 2015. Hubungan antara Spiritualitas dengan Penerimaan Orang Tua pada Orang Tua yang Memiliki Anak Autis. Doctoral Dissertation, Psikologi

[6] Tokala, B. F., Kandou, L. F., \& Dundu, A. E. 2015. Hubungan Antara Lamanya Menjalani Hemodialisis Dengan Tingkat Kecemasan Pada Pasien Dengan Penyakit Ginjal Kronik Di RSUP Prof. Dr. RD Kandou Manado. e-CliniC, 3(1)

[7] Hamid, A. 2009. Bunga Rampai Asuhan Keperawatan 
Integrating chronic kidney disease patient's spirituality in their care: Health benefits and research perspectives. Materia socio-medica, 27(5), 354

[10] Burlacu, A., Artene, B., Nistor, I., Buju, S., Jugrin, D., Mavrichi, I., \& Covic, A. 2019. Religiosity, spirituality and quality of life of dialysis patients: a systematic review. International urology and nephrology, 1-12. 